\title{
Influence of plasma arc and quartz-tungsten- halogen curing lights on the polymerization of orthodontic composite resin
}

\author{
Influência das fontes fotoativadoras xenon e halógena na \\ polimerização de resina composta para colagem ortodôntica
}

\begin{abstract}
Purpose: To analyze, in vitro, the influence of a quartz-tungsten-halogen (QTH) and a plasma $\operatorname{arc}(\mathrm{PAC})$ on the degree of conversion and hardness of a composite resin, as well as the heat generated by the units.

Methods: Transbond XT disks were prepared and light-cured for 10, 20 and 30 seconds with a QTH (Curing Light XL 3000) or with a PAC (Apollo 95E) for 1, 2 and 3 seconds. The composite resin polymerization was evaluated by infrared spectrophotometry (FTIR) and Knoop hardness number (KHN). The temperature at the curing tip was evaluated. The results were analyzed using ANOVA and Tukey test $(\alpha=0.05)$.

Results: According to FTIR and KHN, the polymerization of the composite resin was statistically higher with the QTH. The temperature obtained with the QTH $20 \mathrm{~s}\left(45.44^{\circ} \mathrm{C}\right)$ and $30 \mathrm{~s}$ $\left(45.84^{\circ} \mathrm{C}\right)$ was statistically higher than the QTH $10 \mathrm{~s}\left(39.90^{\circ} \mathrm{C}\right)$. The PAC $1 \mathrm{~s}\left(27.12^{\circ} \mathrm{C}\right), 2 \mathrm{~s}$ $\left(28.48^{\circ} \mathrm{C}\right)$ and $3 \mathrm{~s}\left(29.96^{\circ} \mathrm{C}\right)$ presented the lowest temperature and did not differ statistically among them.

Conclusion: Transbond XT light-activated for 10, 20 and 30 seconds with the QTH presented higher degree of conversion and hardness in comparison with those obtained with the PAC for 1, 2 and 3 seconds, and the QTH generated more heat than the PAC.
\end{abstract}

Key words: Composite resin; degree of conversion; hardness; PAC; QTH

\section{Resumo}

Objetivo: Analisar, in vitro, as fontes luminosas Halógena (QTH) e Xenon (PAC) no grau de conversão e dureza de uma resina composta e também o calor gerado por estas unidades. Metodologia: discos com resina Transbond XT foram fotoativados por 10, 20 e 30 segundos com QTH (Curing light XL 3000) ou com PAC (Apollo 95E) por 1, 2 e 3 segundos. A resina composta foi analisada por meio de espectrofotometria infravermelha (FTIR) e pelo teste de dureza Knoop (KHN). A temperatura na ponta dos aparelhos foi também avaliada. Os resultados foram analisados usando ANOVA e Tuckey test $(\alpha=0.05)$.

Resultados: Conforme FTIR e KHN a polimerização do compósito foi estatisticamente maior com QTH. A temperatura obtida do QTH com 20 segundos $\left(45,44^{\circ} \mathrm{C}\right)$ foi estatisticamente maior do que com 10 segundos $\left(39,90^{\circ} \mathrm{C}\right)$. O PAC com 1, 2 e 3 segundos apresentou as temperaturas mais baixas e não diferem estatisticamente entre si.

Conclusão: A resina Transbond XT fotoativada por 10, 20 e 30 segundos com QTH apresentou maior grau de conversão e dureza em comparação com PAC por 1, 2 e 3 segundos. O QTH produziu mais calor que o PAC.

Palavras-chave: Resina composta; grau de conversão; dureza; QTH; PAC

\author{
Telmo Bandeira Berthold a,b \\ Guilherme Cerveira ${ }^{b}$ \\ Roger Berthold ${ }^{b}$ \\ Luciane Hahn ${ }^{c}$ \\ Ana Maria Spohr ${ }^{b}$ \\ Ernani Menezes Marchioro b
}

- School of Dentistry, Federal University of Rio Grande do Sul, Porto Alegre, RS, Brazil

bSchool of Dentistry, Pontifical Catholic University

of Rio Grande do Sul, Porto Alegre, RS, Brazil

c Private practice, Porto Alegre, RS, Brazil
Correspondence:

Telmo Bandeira Berthold

Pontifical Catholic University of Rio Grande do Sul

(PUCRS) - School of Dentistry

Av. Ipiranga 6681, Building 6

Porto Alegre, RS - Brazil

90616-900

E-mail: tberthold@via-rs.net

Received: July 19, 2011

Accepted: November 25, 2011

Conflict of Interests: The authors state that there are no financial and personal conflicts of interest that could have inappropriately influenced their work.

Copyright: (c) 2011 Berthold et al.; licensee EDIPUCRS. This is an Open Access article distributed under the terms of the Creative Commons AttributionNoncommercial-No Derivative Works 3.0 Unported License. 


\section{Introduction}

In Orthodontics, bonding offers many advantages when compared with conventional banding, such as esthetics, rapidity and simplicity, comfort for the patient, more precise bracket positioning, better gingival and periodontal conditions and better access for cleaning (1). Light-cured materials for bracket bonding present more advantages than chemically-cured ones, as the application of a single paste, more accurate bracket positioning, reduced risk of contamination, easy removal of excess bonding material, and immediate insertion of the arch (2).

Different curing lights may be used when light polymerizing composite resins. The quartz-tungsten-halogen (QTH) lamps emit light when electrical power heats a small tungsten filament and increases the temperature. Most of the energy put into the system is transformed into heat and a small portion is released as light. Light sensitive photoinitiating molecules present in the material are activated, creating free radicals that start the polymerization process (3). According to the manufacturers, the QTH unit can polymerize dental composite resins in 20 seconds, and compomers in 40 seconds for each bracket. This long polymerization time is unpleasant for the patient, impracticable with children and inconvenient for the clinic (4).

The development of light polymerization technology provided the introduction of light-emitting diode (LED) and plasma arc (PAC) light-curing units. The advantages of LED are: coincidence of peak irradiance of LED light with camphorquinone $(5,6)$; a lamp duration time of approximately 10,000 hours (7); no heat generation, and resistance to impacts $(2,7)$; the appliance consumes little power and can be run on rechargeable batteries, allowing it to have a lightweight, ergonomic design (8). These light units are an alternative to QTH units $(9,10)$. The PAC was introduced as an alternative for fast polymerization. This appliance emits high intensity irradiation, over $1000 \mathrm{~mW} / \mathrm{cm}^{2}$, enabling polymerization to be obtained in a shorter period of time. Although this unit needs a filter system, it enables light to be filtered in a narrow wavelength (11).

Therefore, bonding associated with the improvement in materials and light-curing units has brought benefits to the various dentistry specialities. In the specific case of orthodontic traction of retained teeth, the maneuvers required for accessory bonding (hook, button, chain, bracket) were made a great deal easier, however, the work field continues to be unfavorable, due to the difficulty of access and the presence of blood and exudates. This justifies the need for fast and safe polymerization, and light-curing units with high intensity light, such as the PAC with over $1000 \mathrm{~mW} / \mathrm{cm}^{2}$, have been suggested. However, PAC light may bring about a considerable increase in temperature.

The aim of this study was to assess the degree of conversion and the hardness of a composite resin for orthodontic bonding submitted to light-curing by two different light sources: QTH light for 10, 20 and 30 seconds, and PAC light for 1, 2 and 3 seconds of light-activation. The heat generated by each light source has also been assessed at each of the times.

\section{Materials and methods}

\section{Spectrophotometry}

Thirty cylindrical stainless steel metal matrices were made with an external diameter of $10 \mathrm{~mm}$, internal diameter of $8 \mathrm{~mm}$ and a thickness of $1.5 \mathrm{~mm}$. Each matrix was inserted into the hollow of a metal plate. The matrix/metal plate set was put over the attenuated total reflection (ATR) accessory crystal of zinc selenite (Ze-Sn) located in the infrared spectrophotometer (FTIR). The purpose of the metal plate was to obliterate the remaining crystal space, as well as to standardize the distance of $1 \mathrm{~mm}$ between the curing tip and the composite resin.

The assessment sequence for each test specimen was as follows:

a. the bottom spectrum - with all the artifacts (Nujol, cylindrical matrix, metal plate and cover with black background of the appliance itself) and without the composite resin. The purpose of this measurement was to deduct the spectra of artifacts used in the assessment. Nujol is a pure mineral oil (Schering Laboratory Plough, Kenilworth, New Jersey, USA), and was applied on the crystal to prevent composite resin from adhering to it.

b. the monomer spectrum - the composite resin Transbond XT (3M-Unitek, St. Paul, Minessota, USA) was put into the matrix directly from the syringe until it was filled, and then flattened with a spatula. Afterwards, the appliance cover was replaced and the reading made.

c. the polymer spectrum - the cover was removed and the composite resin was light-cured in accordance with the experimental group: QTH light (Curing Light XL 3000, 3M-Unitek, St. Paul, Minnesota, USA) with $620 \mathrm{~mW} / \mathrm{cm}^{2}$ intensity with light-cure times of 10, 20 and 30 seconds; PAC light (Apollo ${ }^{\circledR}$ 95E, DenMed Technologies, Woodland Hills, California, USA) with $1600 \mathrm{~mW} / \mathrm{cm}^{2}$ intensity with light-cure times of 1, 2 and 3 seconds. All the measurements were taken at a resolution of $4 \mathrm{~cm}^{1}$ and 4 internal scans per reading. For each time, five specimens were made. Information about the appliances is given in Table 1.

The spectra of the monomers and their respective polymers were compared to determine the conversion rate of the double bonds into simple carbon bonds. The peaks were measured at the frequencies of $1608.00 \mathrm{~cm}^{-1}$ (corresponding to the aromatic ring bonds) and $1636.00 \mathrm{~cm}^{-1}$ (corresponding to the bonds between carbons of the methacrylate groups) (12). The following formula was used to calculate the conversion rate of the double carbon bonds into simple bonds (13):

$$
\% \text { Conversion }=100 \cdot 1-\frac{\text { Polymer }(\mathrm{C}=\mathrm{C}) \cdot \operatorname{Monomer}(\mathrm{C}-\mathrm{C})}{\operatorname{Monomer}(\mathrm{C}=\mathrm{C}) \cdot \operatorname{Polymer}(\mathrm{C}-\mathrm{C})}
$$


Table 1. Information about the appliances according the manufacturers' specifications.

\begin{tabular}{|c|c|c|c|c|c|}
\hline $\begin{array}{c}\text { Characteristics } \\
\text { Unit }\end{array}$ & Light & $\begin{array}{l}\text { Wave length } \\
(\mathrm{nm})\end{array}$ & $\begin{array}{l}\text { Tip diameter } \\
(\mathrm{mm})\end{array}$ & $\begin{array}{l}\text { Light intensity } \\
\left(\mathrm{mW} / \mathrm{cm}^{2}\right)\end{array}$ & Manufacturer \\
\hline $\begin{array}{l}\text { Curing Light }{ }^{\circledR} \\
\text { XL } 3000\end{array}$ & Quartz-tungsten-halogen & $420-500$ & 8 & $620^{*}$ & 3M Unitek USA \\
\hline Apollo ${ }^{\circledR} 95 \mathrm{E}$ & Plasma arc & $460-490$ & 8 & 1600 & $\begin{array}{c}\text { DenMed Technologies } \\
\text { USA }\end{array}$ \\
\hline
\end{tabular}

* Light intensity was gauged with a radiometer (EFOS - Cure Rite Radiometer, Model 8000 - USA)

\section{Knoop hardness}

Thirty metal matrices with the same dimensions as described for the spectrophotometry test were made. The metal matrix was placed on a glass plate, interposed by a polyester strip. The matrix was filled with composite resin Transbon XT and flattened with a spatula. The metal matrix with composite resin inserted in it was placed on the metal plate, which allowed the light-activation distance to be standardized $(1 \mathrm{~mm})$. The same light units were used at the same light-cure times, and five specimens were obtained for each time. Immediately after light-cure, the Knoop hardness number (KHN) was measured on the HMV Hardness Tester (Shimadzu, Tokyo, Japan). Three indentations were made on the opposite side of the light incidence, at different areas on the composite resin surface, under a 200-g load for 15 seconds. The final KHN value of each specimen was the arithmetic mean of three measurements.

\section{Temperature at the curing tip}

A temperature gauging device (GTH 1160, Phywe Systeme GmbH \& Co., Goettingen, Germany) was used to assess the heat generated by the light sources at each of the light-cure times. The temperature gauging device pointer was placed at the external tip of the light conductor of the light units. The temperature was recorded directly on the digital display of the device. This procedure was repeated five times for each time and the arithmetic mean obtained.

\section{Statistics}

Data were statistically analyzed using analysis of variance and Tukey's multiple comparisons test $(\alpha=0.05)$.

\section{Results}

The QTH 10, 20 and 30 second groups presented statistically higher degree of conversion (\%) than the other groups and did not differ among them. The PAC 2 and 3 seconds groups did not differ statistically between them. The PAC 1 second group presented the lowest degree of conversion and differed statistically from all the other groups $(P<0.05)$ (Table 2).

The QTH 20 and 30 seconds group presented statistically higher KHN than the other groups and did not differ among them. The third highest KHN was obtained for QTH 10 second group, which was statistically higher than those for the PAC groups. The PAC 3 and 2 second groups were those with the lowest KHN, PAC 3 seconds being statistically higher than the PAC 2 seconds $(P<0.05)$. The PAC 1 second group could not be measured (Table 2).

The QTH 20 and 30 second groups presented statistically higher temperatures than the other groups and did not differ among them. The third highest temperature was obtained for the QTH 10 second group, which was statistically higher than those for the PAC groups $(P<0.05)$. The PAC 1,2 and 3 second groups presented the lowest temperatures and did not differ statistically among them (Table 2 ).

Table 2. Polymerization degree (\%), Knoop microhardness number $(\mathrm{KHN})$ and temperature $\left({ }^{\circ} \mathrm{C}\right)$ of the different groups.

\begin{tabular}{cccc}
\hline Group & $\begin{array}{c}\text { Degree of conversion } \\
(\%)\end{array}$ & KHN & $\begin{array}{c}\text { Temperature } \\
\left({ }^{\circ} \mathrm{C}\right)\end{array}$ \\
\hline QTH $-10 \mathrm{~s}$ & $43.42^{\mathrm{a}}$ & $20.53^{\mathrm{a}}$ & $39.90^{\mathrm{a}}$ \\
$\mathrm{QTH}^{-20 \mathrm{~s}}$ & $46.12^{\mathrm{a}}$ & $24.01^{\mathrm{b}}$ & $45.44^{\mathrm{b}}$ \\
$\mathrm{QTH}^{\mathrm{a}}-30 \mathrm{~s}$ & $45.30^{\mathrm{a}}$ & $25.19^{\mathrm{b}}$ & $45.84^{\mathrm{b}}$ \\
$\mathrm{PAC}-1 \mathrm{~s}$ & $23.89^{\mathrm{b}}$ & - & $27.12^{\mathrm{c}}$ \\
$\mathrm{PAC}-2 \mathrm{~s}$ & $32.38^{\mathrm{c}}$ & $10.83^{\mathrm{d}}$ & $28.48^{\mathrm{c}}$ \\
$\mathrm{PAC}-3 \mathrm{~s}$ & $33.77^{\mathrm{c}}$ & $12.80^{\mathrm{e}}$ & $29.96^{\mathrm{c}}$ \\
\hline
\end{tabular}

* Different letters at the columns indicate statistically different mean values $(P<0.05)$

\section{Discussion}

In the present study, two different light-activation sources were used: the QTH (Curing Light ${ }^{\mathrm{TM}}$ XL 3000), because of being the most widely used, and because this unit has also been used as a parameter in other studies $(14,15)$, and the PAC (Apollo ${ }^{\circledR}$ 95E), with high intensity xenon light, because of allowing a significant decrease in light-cure time in comparison with QTH light (11,16-18,20-22). In addition, the effective fixation of brackets in short exposures to light $(2,3,5,6$ or 9 seconds) has aroused great interest among orthodontists $(2,11,20,23)$.

The results of this study indicated a greater degree of conversion of composite resin light-cured by the QTH light in comparison with the PAC light, when assessed by means of FTIR and KHN. This finding is in agreement with the study of Peutzfeldt et al. (14) According to these authors, the degree of conversion is influenced by the energy density presented by the light-curing unit, and the lower the 
energy density, the lower the conversion (Apollo ${ }^{\circledR}$ 95E for $3 \mathrm{~s}=4.1 \mathrm{~J} / \mathrm{cm}^{2}$; Curing Light ${ }^{\circledR}$ XL 3000 for $40 \mathrm{~s}=19.2 \mathrm{~J} / \mathrm{cm}^{2}$ ). They concluded that light-cure with PAC light enables composite resin to be polymerized in less time in comparison with QTH light; however, the properties obtained for the composite resins might not be the most favorable. St-Georges et al. (24) also obtained lower hardness in composite resins light-cured with PAC light in comparison with QTH light. It should be emphasized that although the literature points out much longer times ( \pm 24 hours) to perform these tests after light-curing composite resin, it was opted to perform them immediately, as the loads are immediate in the orthodontic clinic.

The PAC 1 second group could not be gauged in the KHN test, as it did not present the minimum conditions required for assessing the parameters adopted in this research. Bearing in mind the performance of the PAC 1 second group in this study, one agrees with the authors that recommend an increase in exposure time, because low conversion of monomer into polymer propitiates a large quantity of residual monomer, which is toxic to the adjacent tissues $(18,20)$. Furthermore, it is important for the polymerization obtained to be sufficient to fix the bracket on the tooth enamel and bear the orthodontic forces that are applied to it. Research conducted by Sfondrini et al. (23) tested the bond strength of brackets in bovine teeth, in which the materials were light-cured with QTH and PAC lights.

The study of Klocke et al. (15) demonstrated that light-cure with PAC for 1 second provided greater shear strength than the minimum demanded for clinical use in Orthodontics, but the mentioned authors also recommended increasing the exposure time. Sfondrini et al. (25), using Transbon XT and Fuji Ortho LC resin-modified glass ionomer, obtained adequate bond strength values that did not differ statistically when light-cured by PAC and QTH lights. The authors emphasized that polymerization for only 2 seconds with PAC light does not make its clinical use unfeasible.

Heat generation is a concern, as this could be transmitted to the pulp. Bearing in mind that high intensity current lightcuring units are expected to generate a large amount of heat, the temperatures of the PAC and QTH lights were compared at the different light-cure times. A statistically significant difference was observed between the two light-curing units, with the PAC light presenting the lowest mean values that did not differ among them (PAC 1, 2 and 3 seconds).

The short exposure time presented by PAC light is an important variable, because in addition to benefiting the patient and the professional by reducing the bonding time, it makes it feasible to use it at lower temperatures. Pettemerides et al. (20) related that the expectation when using high energy light is that there would be a significant increase in temperature at the tooth surface. However, the results showed that the heat generated by PAC light is less than the heat generated by QTH light, and supposedly this occurs due to the shorter exposure times. The fact that PAC light-curing units generate less heat could be of great value in cases of exposing retained teeth that require accessory bonding, as there is a risk of increased bleeding or injuring tissues.

Polymerization exothermicity is another factor that sets off heat. According to Deb and Sehmi (17) the greater the degree of conversion of double to single bonds the greater the exothermicity. Thus, it is to be expected that composite resin light-cured by QTH light, which had the highest conversion values, would generate more heat. Added to this, at all of its light-cure times, QTH light generated more heat than PAC light, thus it is valid to think that photopolymerization with QTH light generates a higher total temperature than that generated with PAC light. Furthermore, accessory bonding offers two natural barriers (enamel and dentin), the resin itself, and the bracket to prevent damage to the pulp, and it is therefore safe to use a high intensity light sources such as PAC light for this purpose.

Studies examined light sources with low- and highintensity, such as PAC light, and none of them exceeded the pulp temperature of $5.6^{\circ} \mathrm{C}(26,27)$, which corresponds to the critical values and may cause pulp damage (27). The exception was the high-intensity halogen that induced a intrapulpal change of $6.84^{\circ} \mathrm{C}$ (27). Oesterle et al. (16) indicated a light-cure time of 3 seconds of PAC light to polymerize orthodontic adhesives safely as regards pulp temperature.

As regards the undesirable effects, Oesterle et al. (16) raised important considerations with regard to fixation of brackets: 1 - the layer of adhesive is very thin, pressed between the bracket and the tooth; 2 - generally, there is an excess of composite resin at the edges to absorb a little of the contraction; 3 - the contraction would approximate the bracket and the tooth, which is probably an advantage.

Although composite resin light-cured by QTH light had a greater degree of conversion and greater hardness, indicating better quality than resin light-cured with PAC light, according to Sfondrini et al. (2) PAC light is fully satisfactory for bonding, as properties such as coloring, degree of shrinkage, material thickness and pronounced wear are not significant for this purpose.

The results of this and other researches consulted are encouraging for the use of PAC light-curing units for bonding brackets, even with a lower degree of conversion and hardness, when compared with those of QTH lightcuring units.

\section{Conclusions}

Based on the methodology used and analysis of the data obtained in this study, it was possible to conclude that:

1. The composite resin Transbond XT light-cured for 10, 20 and 30 seconds with the QTH light presented higher degree of conversion and higher hardness values in comparison with those obtained with the PAC light for 1, 2 and 3 seconds of light-curing.

2. The QTH light generated more heat than the PAC light. 
1. Whitehill-Grayson IT. Clinical applications of direct orthodontic bonding systems. Dent Clin North Am $1981 ; 25: 347-55$.

2. Sfondrini MF, Scribante A, Klersy C. Plasma arc versus halogen light curing of orthodontic brackets: a 12-month clinical study of bond failures. Am J Orthod Dentofacial Orthop $2004 ; 125: 342-47$.

3. Dunn WJ, Taloumis LJ. Polymerization of orthodontic resin cement with light-emitting diode curing units. Am J Orthod Dentofacial Orthop 2002;122:236-41.

4. Cacciafesta V, Sfondrini M F, Scribante A. Plasma arc versus halogen light-curing of adhesive-precoated orthodontic brackets: a 12-month clinical study of bond failures. Am J Orthod Dentofacial Orthop 2004;126:194-9.

5. Nicholls JL. Polymerization lights - light energy and wavelength. Quintessence Int 2000;31:688-9.

6. Swift EJ. LED curing lights. J Esthet Restor Dent 2002; 14:206-7.

7. Mills RW, Jandt KD, Ashworth SH. Dental composite of cure with halogen and blue light emitting diode technology. Br Dent J 1999;186:388-91.

8. Wiggins KM, Hartung M, Althoff $O$, Wastian $C$, Mitra SB. Curing performance of a newgeneration light-emitting diode dental unit. J Am Dent Assoc 2004;135:1471-9.

9. Palomares NB, Cal-Neto JP, Sampaio-Filho H, Almeida MA, Miguel JÁ. Effect of highintensity LED units at reduced cueing time on in vitro Bond strength of orthodontic brackets. World J Orthod 2008;9:203-8.

10. Penido SM, Penido CV, Dos Santos-Pinto A, Gandini LG, Bagnato VS. In vivo and in vitro study of the shear bond strength of brackets bonded to enamel using halogen or LED light. World J Orthod 2009;10:21-8.

11. Nomoto R, McCabe J F, Hirano S. Comparison of halogen, plasma and LED curing units. Oper Dent 2004;29:287-94.

12. Rueggeberg FA, Hashinger DT, Fairhurst CW. Calibration of FTIR conversion analysis of contemporary dental resin composites. Den Mater 1990;6:241-9.

13. Eliades T, Johnston WM, Elliades $G$. Direct light transmittance through ceramic brackets. Am J Orthod Dentofacial Orthop 1995; 107:11-9.

14. Peutzfeldt A, Sahafi A, Asmussen E. Characterization of resin composites polymerized with plasma arc curing units. Dent Mater 2000;16:330-6.

15. Klocke A, Korbmacher HM, Huck LG, Ghosh J, Kahl-Nieke B. Plasma arc curing of ceramic brackets: an evaluation of shear bond strength and debonding characteristics. Am J Orthod Dentofacial Orthop 2003;124:309-15.

16. Oesterle LJ, Newman SM, Shellhart WC. Rapid curing of bonding composite with a xenon plasma arc light. Am J Orthod Dentofacial Orthop 2001;119:610-6.

17. Deb S, Sehmi H. A comparative study of the properties of dental resin composites polymerized with plasma and halogen light. Dent Mater 2003; 19:517-22.

18. Dietschi D, Marret N, Krejci I. Comparative efficiency of plasma and halogen light sources on composite micro-hardness in different curing conditions. Dent Mater 2003;19:493500.

19. Oyama N, Komori A, Nakahara R. Evaluation of light curing units used for polymerization of orthodontic bonding agents. Angle Orthod 2004;6:808-13.

20. Pettemerides AP, Sherriff M, Ireland AJ. An in vivo study to compare a plasma arc light and conventional quartz halogen curing light in orthodontic bonding. Eur J Orthod 2004;26:573-7.

21. Manzo B, Liistro G, Clerck H. Clinical trial comparing plasma arc and conventional halogen curing lights for orthodontic bonding. Am J Orthod Dentofacial Orthop 2004; $125: 30-5$.

22. Dall'Igna CM, Marchioro EM, Spohr AM, Mora EG. Effect of curing time on the bond strength of a bracket-bonding system cured with a light-emmiting diode or plasma arc light. Eur J Orthod $2011 ; 33: 55-49$

23. Sfondrini MF, Cacciafesta V, Klersy C. Halogen versus high-intensity light-curing of uncoated and pre-coated brackets: a shear bond strength study. J Orthod 2002;29:45-50.

24. St-Georges AJ, Swift EJ, Thompson JY, Heymann HO. Irradiance effects on the mechanical properties of universal hybrid and flowable hybrid resin composites. Dent Mater 2003; 19:406-13.

25. Sfondrini MF, Cacciafesta V, Pistorio A, Sfondrini G. Effects of conventional and highintensity light-curing on enamel shear bond strength of composite resin and resin-modified glass-ionomer. Am J Orthod Dentofacial Orthop 2001;1 19:30-5.

26. Malkoç $S$, Uysal T, Usümez S, Isman E, Baysal A. In vitro assessment of temperature rise in the pulp during orthodontic bnding. Am J Orthod Dentofacial Orthop 2010;137:379. 83.

27. Zach L, Cohen G. Pulp response to externally applied heat. Oral Surg Oral Med Oral Pathol 1965;19:515-30. 